\title{
A seletividade do sistema prisional brasileiro e o perfil da população carcerária \\ Um debate oportuno
}

\author{
The selectivity of Brazilian penitentiary system \\ and the profile of the incarcerated population \\ An opportune debate
}

\author{
Felipe Mattos Monteiro \\ Gabriela Ribeiro Cardoso*
}

\begin{abstract}
Resumo: O debate sobre criminalidade e segurança pública no Brasil é bastante vasto e cercado de polêmicas. No que tange ao sistema prisional, os estudos destacam sua fragilidade e seletividade. Por isso, este trabalho tem como objetivo traçar um perfil do encarcerado brasileiro durante o período de 2005 a 2010, levando em consideração diversas questões como a idade, a escolaridade do preso, a cor, o tempo total da pena, o grau de reincidência, a faixa etária e o crime cometido. Na sequência, desenvolvemos a análise de correlações e regressão entre a taxa da população prisional e os tipos de crimes para abordar a relação entre os dois fatores. Concluímos que tem ocorrido no Brasil o privilegiamento de uma ação "repressiva" ao invés de uma "preventiva", o que contribui para um aumento da população carcerária sem que ocorra um impacto nas taxas de criminalidade. Palavras-chave: Sistema prisional. Seletividade. Segurança pública.
\end{abstract}

Abstract: The debate on crime and public security in Brazil is very wide and surrounded by controversies in public discussions. Regarding the penitentiary system, the studies highlight its fragility and selectivity. Therefore, this paper aims to draw a profile of the incarcerated in the Brazilian states during the period 2005 to 2010, taking into consideration several issues broadly discussed in the literature such as age, educational level of the prisoner, the color, the total fulfillment of the sentence, the level of recidivism, the age group and committed crime. Thereafter, we developed the analysis of correlation and regression between the rate of the prison population and the types of crimes to approach the relationship between the two factors. We conclude that what has occurred in Brazil is the privilege of a "repressive" action rather than a "preventive", which contributes to the increase in prison population without an impact on crime rates.

Keywords: Penitentiary system. Selectivity. Public safety.

* Felipe Mattos Monteiro é mestre em Sociologia Política pela Universidade Federal de Santa Catarina (Ufsc), professor da Universidade Federal da Fronteira Sul (UFFS) em Laranjeiras do Sul, PR, Brasil, e pesquisador do Núcleo Interdisciplinar de Políticas Públicas < malttos@ yahoo.com.br>. Gabriela Ribeiro Cardoso é mestre em Sociologia Política pela Universidade Federal de Santa Catarina (Ufsc) e pesquisadora do Núcleo Interdisciplinar de Políticas Públicas na Ufsc em Florianópolis, SC, Brasil <grcgabi@gmail.com>.

\begin{tabular}{|l|l|l|l|l|l|}
\hline Civitas & Porto Alegre & v. 13 & n. 1 & p. 93-117 & jan.-abr. 2013 \\
\hline
\end{tabular}




\section{Apresentação}

O debate sobre criminalidade e segurança pública no Brasil é bastante vasto e denso, cercado de polêmicas do debate público e refletido até mesmo na produção cinematográfica brasileira, a exemplo de Tropa de elite 2. Na literatura sobre segurança pública, diversos pesquisadores destacam o paradoxo entre o processo de democratização e este campo de política pública, tendo em vista os descompassos entre os avanços ocorridos na esfera política e "os aparatos policial e prisional" que foram resistindo à assimilação de novos padrões da vida democrática. Tal aspecto está expresso na manutenção de práticas arbitrárias e violentas cultivadas durante o período militar, das quais o sistema prisional também merece destaque (Adorno, 2006; Salla; Ballesteros, 2008).

No que tange ao sistema prisional de modo mais específico, os estudos precursores acerca do sistema já apontavam perspectivas alarmantes. Coelho (2005c), ao analisar o sistema penitenciário no estado do Rio de Janeiro durante a década de 1980, o descreve como tendo atingido "o seu grau mais alto de deterioração", no qual quase nada mais funciona em níveis mínimos de eficiência. O sistema só não teria entrado em colapso em decorrência das "soluções irregulares" permitidas de modo a suprir a omissão do Estado na assistência ao preso (Coelho, 2005c, p. 164).

A percepção internacional acerca do sistema carcerário brasileiro também não é das melhores. Como descreve Wacquant (2001), as prisões brasileiras são "campos de concentração para pobres" que mais se assemelham a empresas públicas de "depósito industrial de dejetos sociais" do que instituições que servem para alguma função penalógica (como reinserção). Acompanhando o ritmo de outros países da América Latina como Argentina e Chile, a população carcerária brasileira vem crescendo abruptamente (Salla; Ballesteros, 2008).

O crescimento das taxas de encarceramento no Brasil é acompanhado de formas mais severas do aparato repressivo. As prisões passaram a ter regimes disciplinares mais rígidos, o que se contrapõe com a perspectiva da ressocialização. Neste sentido, as políticas penais adotadas no Brasil, Chile e Argentina foram influenciadas pelos marcos dos países desenvolvidos, mas com grandes diferenças institucionais (Salla; Ballesteros, 2008).

No que se refere às políticas de segurança pública, um debate importante concentra-se nas concepções repressivas e preventivas. O primeiro grupo aponta que as medidas dissuasórias (aparelhamento da polícia, aperfeiçoamento da máquina judicial, maior rigor na aplicação da pena, incremento do encarceramento) são o cerne da ação governamental - o que se aproxima da perspectiva de lei e ordem. Já o segundo grupo aposta nas medidas de inclusão 
social e humanitária (diminuição da desigualdade social e do desemprego, incremento da participação comunitária, valorização da educação, ênfase na ressocialização) - o que se aproxima do destaque aos direitos humanos (Sapori, 2009). Sem aprofundar este debate, convém mencionar ainda que existem pesquisadores que enfatizam a necessidade de aproximar as duas perspectivas, como Sapori (2009) ou, ainda, como Adorno que considera este o grande desafio dos governos democráticos:

Salir de este círculo cerrado que supone la aplicación de la ley y el orden para la protección de los derechos humanos, como si fuesen domínios irreconciliables, constituye el mayor desafio a las políticas públicas de seguridad y justicia formuladas e implementadas por gobiernos democráticamente elegidos (Adorno, 2006, p. 48).

O panorama que será apresentado a seguir sobre o sistema prisional brasileiro confirma o que já vem sendo discutido em outros trabalhos (Adorno, 2006; Salla, 2003; Salla; Ballesteros, 2008; Lemgruber, 2001), de que existe um endurecimento na aplicação das penas, um encarceramento massivo, violações de direitos humanos, o que por sua vez agrava a segregação dos sentenciados. Entretanto, este encarceramento massivo corresponde a um perfil específico e seletivo da população.

O presente artigo está organizado em quatro partes principais. Inicialmente, apresentamos algumas críticas sobre os dados utilizados; na sequência, caracterizamos o sistema prisional brasileiro; e o perfil da população prisional brasileira. Por último, desenvolvemos a análise de correlações e regressão entre a taxa da população prisional e os tipos crimes. Nas considerações finais, aproximamos as nossas análises de algumas contribuições de Agamben (2004; 2010).

\section{Sobre os dados}

Para o estudo empírico utilizamos os dados disponibilizados pelo Sistema Integrado de Informações Penitenciárias (Infopen). Segundo o próprio Ministério da Justiça (2011), este sistema de informações foi criado com o objetivo de construir um banco de dados unificado que pudesse agregar dados federais e estaduais sobre os estabelecimentos penais e a população penitenciária. Nele é possível ter acesso a uma série de informações sobre o sistema prisional e o perfil da população carcerária.

No processo de análise das informações, algumas dificuldades foram encontradas. Os dados disponíveis, além de estarem organizados de forma que vem a dificultar sua operacionalização -, apresentam inúmeras inconsistências. 
Muitos estados deixam de prestar informações relevantes, como é o caso do Rio de Janeiro, que não informou a quantidade de óbitos ocorrida em seu sistema prisional no primeiro semestre de 2007.

Embora os estados que firmaram o convênio com o Fundo Penitenciário Nacional (Funpen) tenham a obrigação de manter os dados atualizados, não é esta a realidade que nos deparamos no exame das informações. Devido a essas inconsistências, muitas de nossas análises estão limitadas, seja pela forma em que os dados estão organizados, seja pela carência dos mesmos. A publicação das informações implica diretamente no debate sobre as políticas de segurança que se constituem em uma área alvo de considerações tantas vezes arbitrárias e não pautadas em indicadores conclusivos. Fornecer os dados por meio de livre acesso através do site do Ministério da Justiça já é um grande avanço, contudo, é essencial não perder de vista a excelência no próprio trabalho para não parecer apenas uma necessidade de fazê-lo em face às pressões externas. É um compromisso público estendido a todos os estados, para que se possa contrapor o presente momento com anteriores, que marcavam os pesquisadores pelo descrédito na utilização de estatísticas oficiais por uma série de fatores.

Apesar das limitações, consideramos ainda assim muito relevante a abordagem estatística que expressa quantos são e quem são aqueles considerados "legalmente" enquanto criminosos. Sobretudo no caso das prisões, torna-se possível visualizar aqueles que de fato são punidos, em decorrência do afunilamento do próprio sistema de justiça criminal. Essas falhas, além de dificultarem as análises, podem prejudicar o valor conceitual das conclusões apresentadas, no entanto, mesmo com esses agravantes, entendemos que a avaliação e estudo dos dados devem ser realizados, seja para contribuir na melhora das informações, seja para conhecer as instituições pesquisadas.

Contudo, é possível perceber uma melhora na disponibilização das informações com o passar dos anos. Antes de 2003, os dados publicizados eram bastante precários e a maioria das informações resumiam-se a caracterizar contextos bastante gerais. De 2005 a 2010, podemos encontrar informações mais substantivas, capazes de demonstrar direcionamentos em busca de uma avaliação mais precisa do sistema prisional brasileiro.

\section{O sistema prisional brasileiro}

No contexto brasileiro, a população prisional no ano de 2000 correspondia a um total de 232.755 , ao passo que, em 2010, esse número havia modificado para 496.251 presos. Comparado aos Estados Unidos, o número é muito inferior, no entanto o crescimento da população carcerária em um período de 10 anos, mais que dobrou e alcançou um incremento de 113,2\%. 
Gráfico 1. População prisional do Brasil no período de 2000 a $2010^{1}$

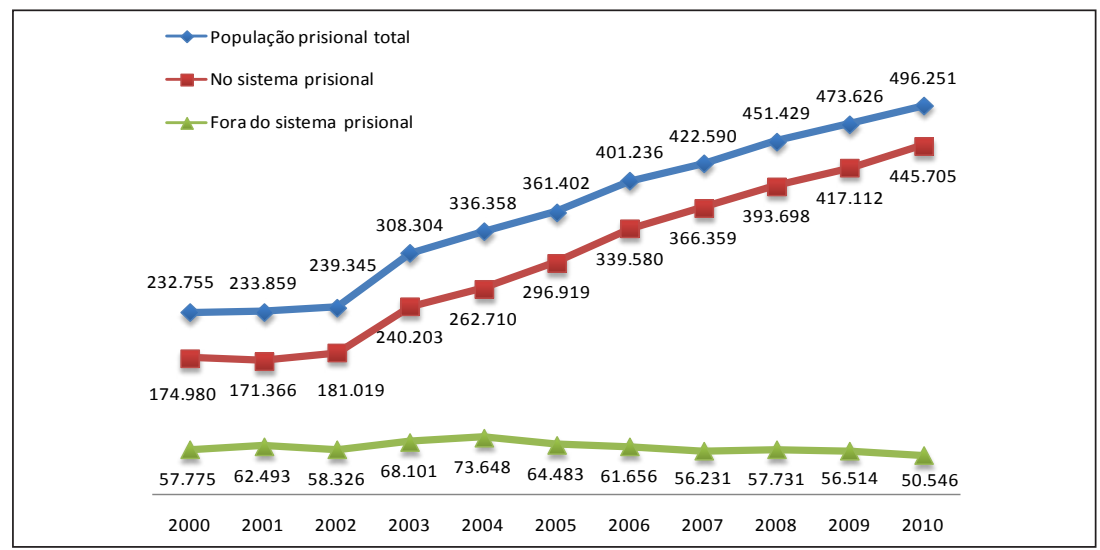

Fonte: BRASIL. Ministério da Justiça. Departamento Penitenciário Nacional - Sistema Integrado de Informação Penitenciária(Infopen). Brasília, 2011. Disponívelem: <http://portal.mj.gov.br/data/Pages/MJD 574E9CEITEMIDC37B2AE94C6840068B1624 D28407509CPTBRNN.htm>. Acesso em: 10 jun. 2011. Org.: Os autores.

Gráfico 2. Taxa da população prisional do Brasil no período de 2000 a $2010^{2}$

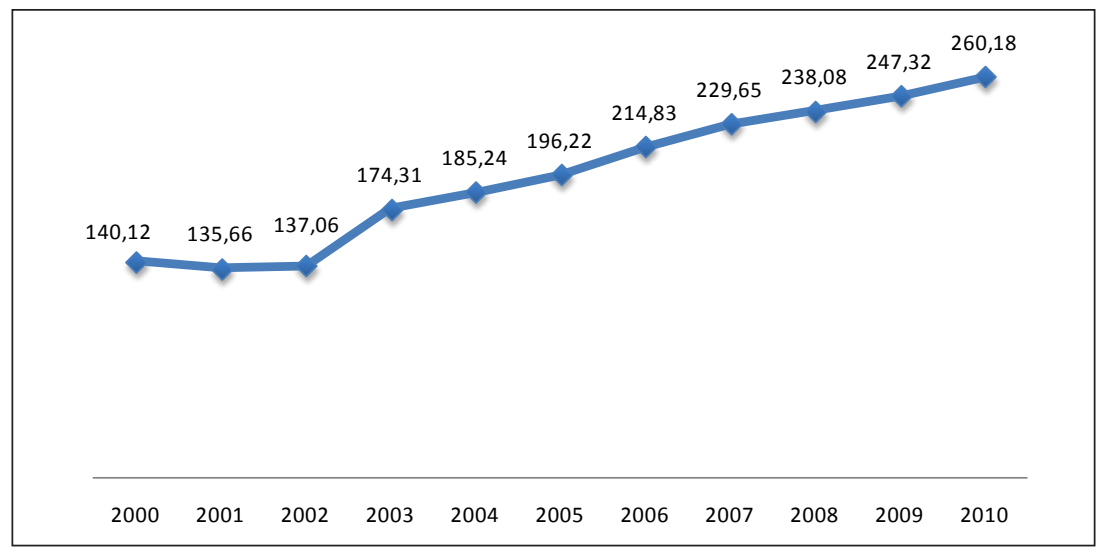

Fonte: BRASIL. Ministério da Justiça. Departamento Penitenciário Nacional - Sistema Integrado de InformaçãoPenitenciária (Infopen). Brasília, 2011.Disponívelem: $<$ http://portal.mj.gov.br/data/Pages/MJD 574E9CEITEMIDC37B2AE94C6840068B1624D28407509CPTBRNN.htm>. Acesso em: 10 jun. 2011. IBGE: Estimativas populacionais para o TCU.

Org.: Os autores.

Dados relativos a junho de 2010 .

2 Taxa por 100.000 habitantes: razão entre a população prisional e a população total brasileira de cada ano multiplicado por 100.000 . 
Em relação à taxa da população prisional, os resultados demonstram que a população carcerária cresce de forma elevada mesmo em comparação ao número de habitantes. Como descreve Salla (2003), em um período de cinco anos (1995 a 2000), o crescimento foi de $41 \%$. O autor aponta a superlotação como um dos problemas crônicos e que caminha ao lado da existência de um déficit nas vagas do sistema prisional. Embora tenham sido criadas 35 mil vagas de 1995-2000, o déficit permanece, como é evidenciado na constante de presos fora do sistema. Enquanto, no ano de 2000, a cada 100.000 pessoas, 140,12 delas estavam presas, em 2010, de 100.000 pessoas, 260,18 encontravam-se em reclusão, o que revela um quadro agravante e sem precedentes.

O número de presos provisórios obteve, somente no ano de 2003 a 2010, o aumento de 97.134 pessoas, o que expressa um incremento de mais de $143 \%$. No ano de 2010 , esse fator é ainda mais preocupante: $33,1 \%$ de todas essas pessoas ainda esperavam por julgamento. Desta forma, registra-se a incapacidade do estado em absorver esse contingente de "novos" presos, como o atraso da justiça em julgar esses processos e a legitimação de políticas que incentivem o encarceramento.

Gráfico 3. Número de presos provisórios do Brasil no período de 2000 a $2010^{3}$

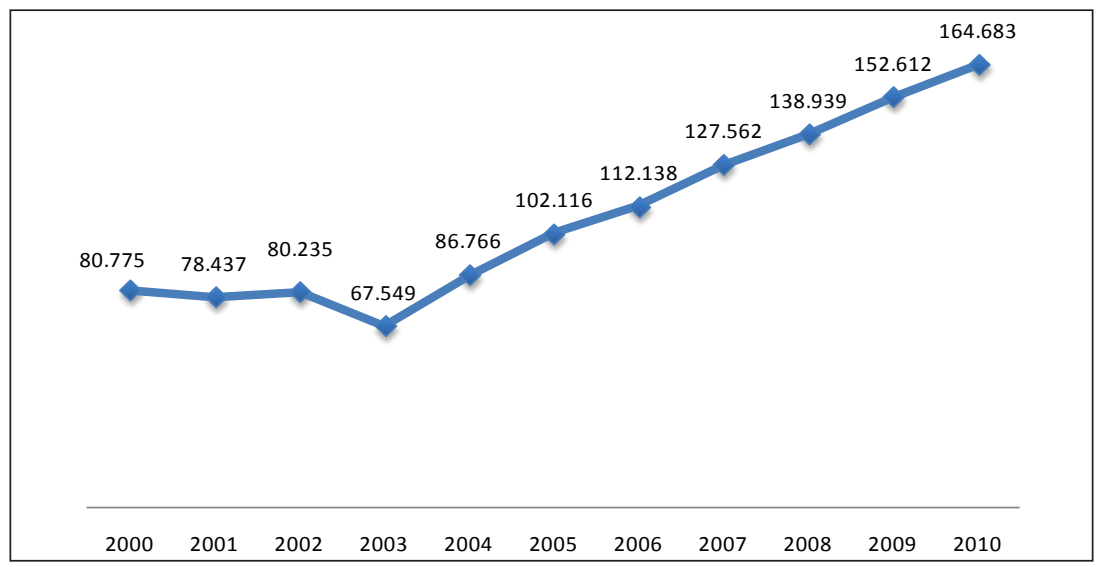

Fonte: BRASIL. Ministério da Justiça. Departamento Penitenciário Nacional - Sistema Integrado de Informação Penitenciária(Infopen). Brasília, 2011.Disponível em: $<$ http://portal.mj.gov.br/data/Pages/MJD 574E9CEITEMIDC37B2AE94C6840068B1624D28407509CPTBRNN.htm>. Acesso em: 10 jun. 2011. Org.: Os autores.

3 A queda verificada no total de presos provisórios no ano de 2003 pode ter ocorrido mais por um erro na gerência das informações do que por uma ação adotada pelo estado para diminuir o número de presos provisórios. Consideramos esta possibilidade porque em muitos casos alguns estados deixaram de enviar suas informações para o Infopen. 
As políticas fomentadas pelo governo federal se voltaram para questões emergenciais - de modo mais explícito para a criação de mais vagas em decorrência da superpopulação - e deixaram de atacar questões importantes ligadas ao sistema prisional, que contribuem para a manutenção de graves problemas. Dessa forma, verificamos o inchaço sem precedentes do sistema penitenciário brasileiro e o incentivo a políticas repressivas respaldadas por uma lógica de encarceramento. Em um período de 15 anos, o Brasil gastou R \$ 1.530.975.617 (92\%) em construção, ampliação e reformas dos presídios, apenas $\mathrm{R} \$ 44.283 .052$ (3\%) em atividades para a formação dos apenados e R \$ 81.944.379 (5\%) em penas alternativas. Essas questões continuam presentes, seja pela atuação de órgãos da secretaria de segurança pública em resposta às pressões midiáticas, seja pelo incremento no número da população penitenciária aliada à constância no déficit de vagas.

O gráfico 4 é relevante, pois possibilita identificar os tipos de gastos do Funpen no decorrer do período de 1995 a 2010, e visualizar a discrepância entre as iniciativas construção, ampliação e reforma dos presídios em comparação com as medidas alternativas. No que tange aos dados de penas alternativas, convém mencionar que o ápice atingido no ano de 2002 pode ter como hipótese explicativa a criação de políticas específicas pelo Ministério da Justiça.

\begin{abstract}
Em setembro de 2000, o Ministério da Justiça lançou o Programa Nacional de Apoio às Penas Alternativas como diretriz do Conselho Nacional de Política Criminal e Penitenciária - CNPCP, executado pela gerência da Central Nacional de Apoio e Acompanhamento às Penas e Medidas Alternativas - Cenapa, subordinada à Secretaria Nacional de Justiça, com o objetivo de realizar as ações necessárias ao incremento da aplicação das penas alternativas no Brasil, através de assessoria, informação e capacitação para instalação de equipamentos públicos em todo território nacional, financiados pelo Fundo Penitenciário Nacional - Funpen (Brasil, 2008, p. 2 - grifo do original).
\end{abstract}

As condições de habitabilidade são muito perversas. Mesmo com o crescimento do número de vagas, o sistema prisional não é capaz de dar conta da demanda. Em 2010, existiam 281.520 vagas no sistema prisional para uma população de 496.251 pessoas, ou seja, uma superpopulação de presos ultrapassando mais da metade do número de vagas. 
Gráfico 4. Tipos de gastos do Funpen ${ }^{4}$ nos estados de 1995 a 2010

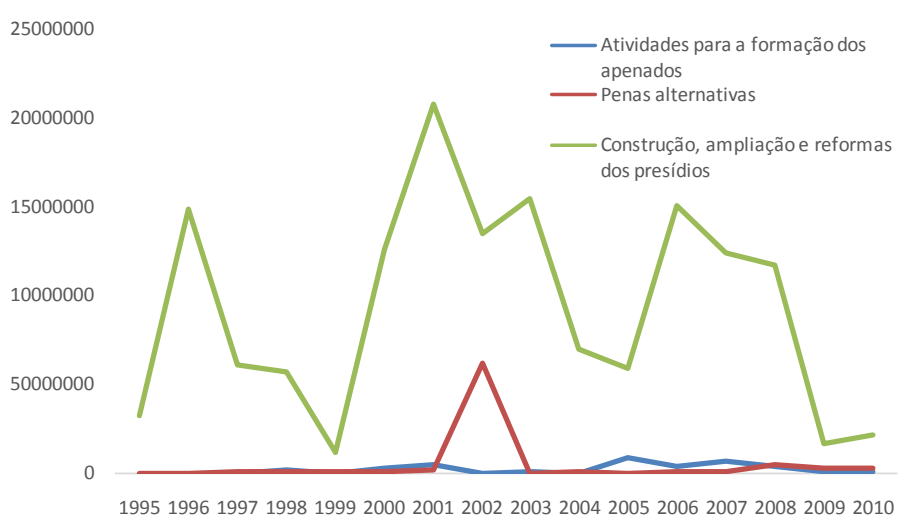

Fonte: BRASIL. Ministério da Justiça. Departamento Penitenciário Nacional - Sistema Integrado de InformaçãoPenitenciária(Infopen).Brasília,2011.Disponívelem: $<$ http://portal.mj.gov.br/data/Pages/MJD 574E9CEITEMIDC37B2AE94C6840068B1624D28407509CPTBRNN.htm>. Acesso em: 10 jun. 2011. Org. Os autores.

Gráfico 5. Número de vagas no sistema prisional do Brasil no período de 2000 a $2010^{5}$

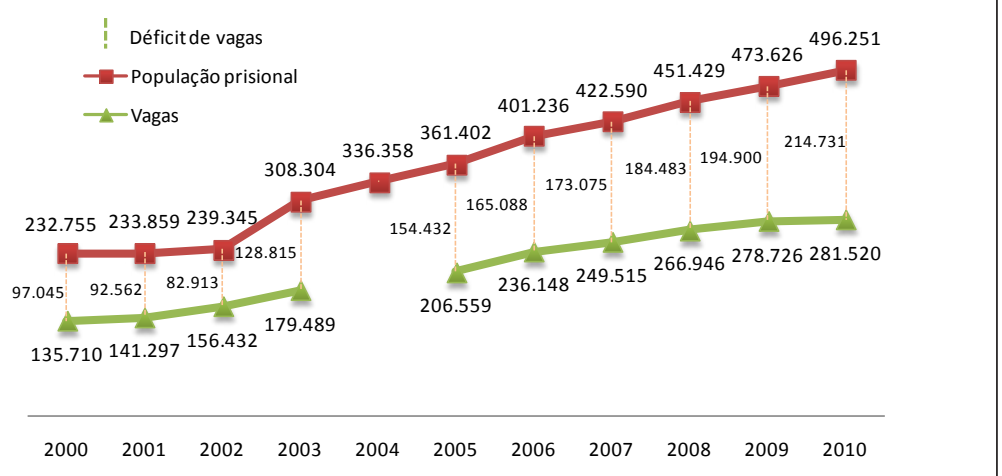

Fonte: BRASIL. Ministério da Justiça. Departamento Penitenciário Nacional - Sistema Integrado de Informação Penitenciária(Infopen). Brasília, 2011.Disponívelem: $<$ http://portal.mj.gov.br/data/Pages/MJD 574E9CEITEMIDC37B2AE94C6840068B1624D28407509CPTBRNN.htm>. Acesso em: 10 jun. 2011. Org.: Os autores.

4 O Fundo Penitenciário Nacional (Funpen) foi criado em 1994 e tem como finalidade "[...] proporcionar recursos e meios para financiar e apoiar as atividades de modernização e aprimoramento do Sistema Penitenciário Brasileiro" (Brasil, 2010, p. 6).

5 O déficit de vagas é resultado da subtração da população prisional pelo número de vagas disponibilizado. 
Para Macaulay (2006), as condições de detenção são extremamente "cruéis, desumanas e degradantes" e, combinadas com a ausência do Estado, levaram a processos bastante complicados, como as inúmeras rebeliões e ao aumento da capacidade estratégica do crime organizado. Esta relação com o crime organizado também é destacada por Adorno (2006) como uma das consequências da política de maior encarceramento. $\mathrm{O}$ crescimento dos grupos criminosos, por sua vez, elevou a tensão dentro das prisões que aumentaram os conflitos internos. Segundo dados do Ministério da Justiça (Brasil, 2011), em 1994, a taxa de homicídios da população encarcerada foi de 1,01 por grupo de cem mil presos, 13 vezes superior a encontrada nos EUA $(0,08)$ durante o mesmo período (Salla, 2003). Em 2009, no sistema prisional brasileiro, a taxa de óbitos criminais foi de 12,2 para cada grupo de 100.000 presos. Em 15 anos, ocorreu um acréscimo de $1.107 \%$ nas taxas de óbitos criminais, o que expressa a alta letalidade das prisões e a vida dos presos exposta a todo sacrifício. ${ }^{6}$

A situação brasileira é altamente preocupante e revela o desleixo por parte da sociedade e dos mecanismos de segurança pública com esses grupos sociais. O ambiente é de extrema deterioração, não só das condições de infraestrutura, mas da dignidade humana. Esse dado por sua vez, revela um quadro mais agravante do que o norte-americano, que, embora apresente uma enorme população carcerária, resguarda alguns "direitos básicos", como condições de sobrevivência. ${ }^{7}$

\section{O perfil da população da carcerária}

Com base nos dados estatísticos do sistema prisional, procuramos traçar um perfil do encarcerado, levando em consideração diversas questões amplamente discutidas na literatura: a idade, a escolaridade do preso, a cor, o tempo total da pena, o grau de reincidência, a faixa etária e o crime cometido. Chamamos atenção para o "aspirador social" que se tornou o sistema prisional brasileiro, no qual o aumento de sua população deve-se mais a uma política de repressão e de criminalização à pobreza, do que a uma política capaz de diminuir as ocorrências criminais. Torna-se importante colocar o debate sobre a criminalidade em um plano que leve em consideração questões sobre desigualdade social e econômicas enquanto elementos partícipes dessa "equação", acompanhados da discussão sobre o acesso à justiça.

6 O que remete à ideia de "vida sem valor" desenvolvida por Agamben (2010), ou seja, a morte que não é reclamada.

7 Outras questões referentes às condições de habitabilidade não serão aqui abordadas em face da multiplicidade de variáveis a serem destacadas e que demandariam análises mais detalhadas. 
Quando se trata da problemática da violência, os jovens assumem posição de destaque. Por exemplo, as taxas de homicídios são maiores entre os grupos de jovens. Segundo dados do Mapa da Violência (2010), ${ }^{8}$ as vítimas na faixa de 15 a 24 anos de idade representaram $36,6 \%$ do total de homicídios no país. Diante de tal cenário, convencionou-se afirmar que ao mesmo tempo em que os jovens são vítimas de homicídios, eles também são os algozes, ou seja, os jovens são os que mais morrem, mas também são os que mais matam. Entretanto, muitos estudos vêm demonstrando o contrário: os jovens do sexo masculino são as vítimas e não os agressores.

Gráfico 6. Percentual de presos do Brasil por faixa etária em 2010

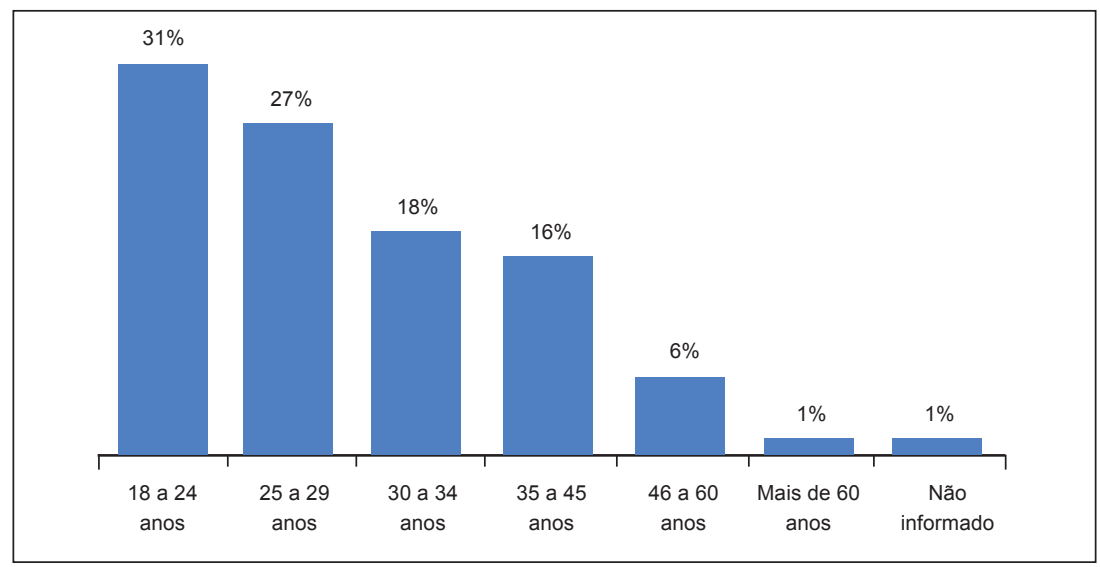

Fonte: BRASIL. Ministério da Justiça. Departamento Penitenciário Nacional - Sistema Integrado de InformaçãoPenitenciária(Infopen).Brasília,2011.Disponívelem: $<$ http://portal.mj.gov.br/data/Pages/MJD 574E9CEITEMIDC37B2AE94C6840068B1624D28407509CPTBRNN.htm>. Acesso em: 10 jun. 2011. Org.: Os autores.

Os jovens não são apenas as vítimas de homicídios, são também alvos fáceis do processo de criminalização e seletividade do sistema penal. De toda a população prisional brasileira em 2010, 58\% encontravam-se na faixa de 18 a 29 anos. É um quadro complexo que se delineia com a inserção precoce nas penitenciárias e contribui para uma "carreira criminosa". O cenário tornase mais preocupante na medida em que a maioria das pessoas que estão no sistema prisional cometeu delitos enquadrados no grande grupo "crimes contra o patrimônio" (51,9\%). Além disso, de todos esses crimes, 83,5\% 8 Disponível em $<$ http://www.sangari.com/mapadaviolencia/mapa2010.html $>$. Acesso em: 10
jun. 2011 . 
foram de roubo e furto e apenas $6,1 \%$ latrocínio (roubo seguido de morte). Crimes graves, como os de homicídios ou mesmo de tráfico internacional de drogas apresentaram percentuais baixos em relação aos outros crimes ligados à propriedade. Em relação a crimes que estão vinculados à qualificação e maior tempo desprendido no planejamento e execução, como os crimes contra a fé pública ou contra a administração pública, os percentuais não chegam a $1 \%$.

Gráfico 7. Percentual de crimes consumados em 2010 (Prisões do Brasil) ${ }^{9}$

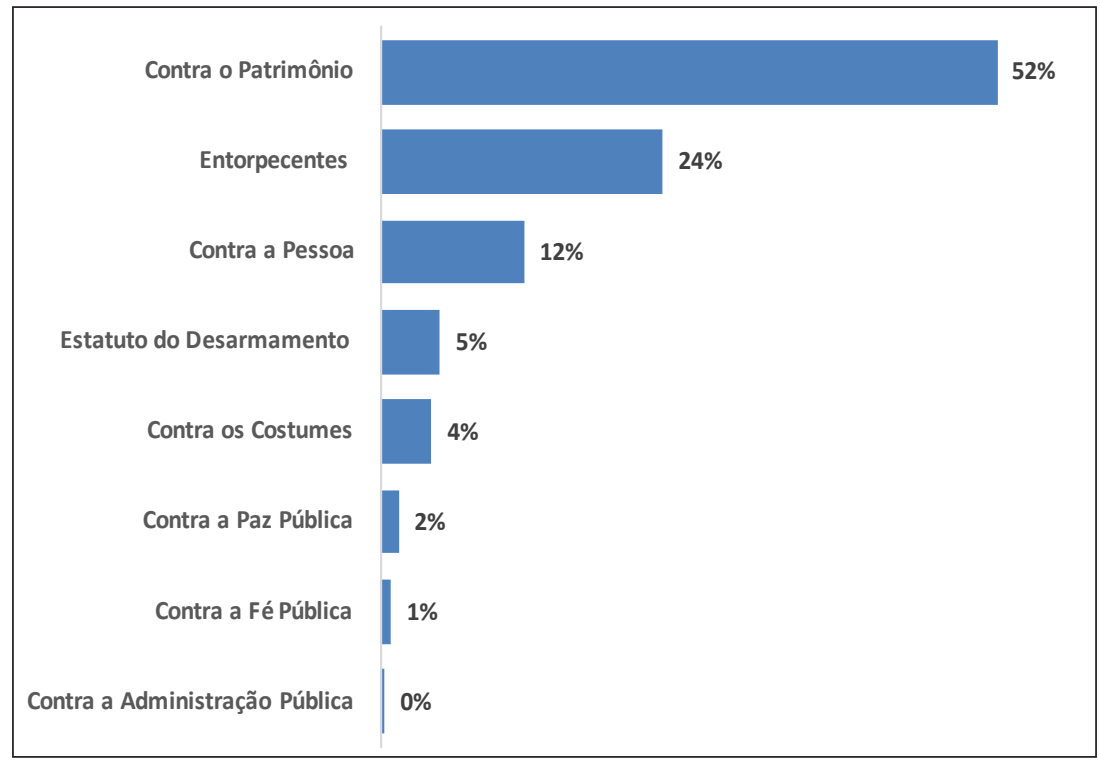

Fonte: BRASIL. Ministério da Justiça. Departamento Penitenciário Nacional - Sistema Integrado de Informação Penitenciária(Infopen). Brasília,2011.Disponívelem: $<$ http://portal.mj.gov.br/data/Pages/MJD 574E9CEITEMIDC37B2AE94C6840068B1624D28407509CPTBRNN.htm>. Acesso em: 10 jun. 2011. Org.: Os autores.

Inúmeras modalidades de crimes aumentaram nos últimos anos no país, especialmente os crimes de homicídios. Assim, tomando-se como ponto de partida algumas estatísticas sobre o Brasil, as taxas de homicídios vêm crescendo abruptamente, com total atenção a região nordeste. Esperar-se-ia que um sistema de justiça e uma polícia judiciária agissem de maneira mais eficiente em relação a esses crimes; de todas as pessoas presas no Brasil no ano

9 Ver apêndice A. 
de 2010 , apenas $12,1 \%$ cometeram crimes contra a pessoa, ou seja, homicídios e sequestro. Em um quadro de alto crescimento das modalidades de crimes fatais, parece-nos preocupante constatar que apenas $12,1 \%$ realizaram tais ações.

O caso brasileiro assemelha-se ao norte-americano. As prisões não estão repletas de criminosos perigosos e violentos, mas de condenados por negócios com drogas, furto, roubo ou atentados à ordem pública, ou seja, condenados caracterizados por crimes não violentos. Wacquant (2001) aponta que a penalidade neoliberal é norteada pelo paradoxo de remediar com "mais Estado" policial e penitenciário o "menos Estado" econômico e social. A análise desenvolvida pelo autor do sistema penitenciário norte-americano enfatiza o alto crescimento da população carcerária enquanto um fenômeno sem precedentes, o qual é acompanhado de uma verdadeira "indústria da carceragem" que faz das prisões o $3^{\circ}$ maior empregador nos Estados Unidos. Os “clientes naturais" das prisões da miséria são os negros, latinos, com baixa renda familiar, oriundos de famílias do subproletariado e condenados pelo direito comum por envolvimento com drogas, furto, roubo ou atentados à ordem pública, em grande parte, pequenos delitos.

Gráfico 8. Percentual de presos por tempo total das penas em 2010 no Brasil

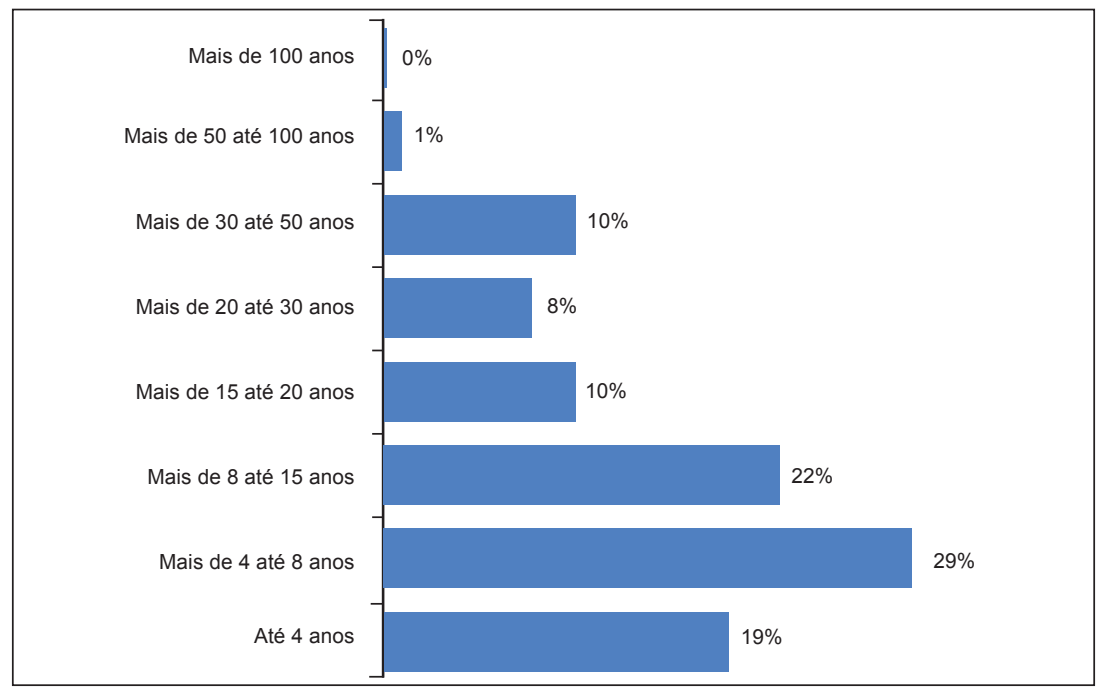

Fonte: BRASIL. Ministério da Justiça. Departamento Penitenciário Nacional - Sistema Integrado de Informação Penitenciária(Infopen). Brasília, 2011.Disponível em: $<$ http://portal.mj.gov.br/data/Pages/MJD 574E9CEITEMIDC37B2AE94C6840068B1624D28407509CPTBRNN.htm>. Acesso em: 10 jun. 2011. Org.: Os autores. 
Em 2010, 48\% dos presos encontravam-se na faixa de 1 a 8 anos. Os presos com o tempo total da pena de até 4 anos, normalmente, são aqueles que cometaram pequenos crimes, o que representa $19 \%$ de todos os presos encarcerados em 2010. Priviligia-se uma política de encarceramento que está baseada muitas vezes na pressão da sociedade e da mídia por mais segurança. Em nenhum momento ocorre a problematização dessas ações e nem mesmo o mínimo de reflexão sobre as causas que levaram a uma situação tão crítica. É necessário conhecer essa dinâmica, e especialmente as pessoas que estão sendo presas.

Gráfico 9. Percentual de presos por grau de instrução em 2010 no Brasil

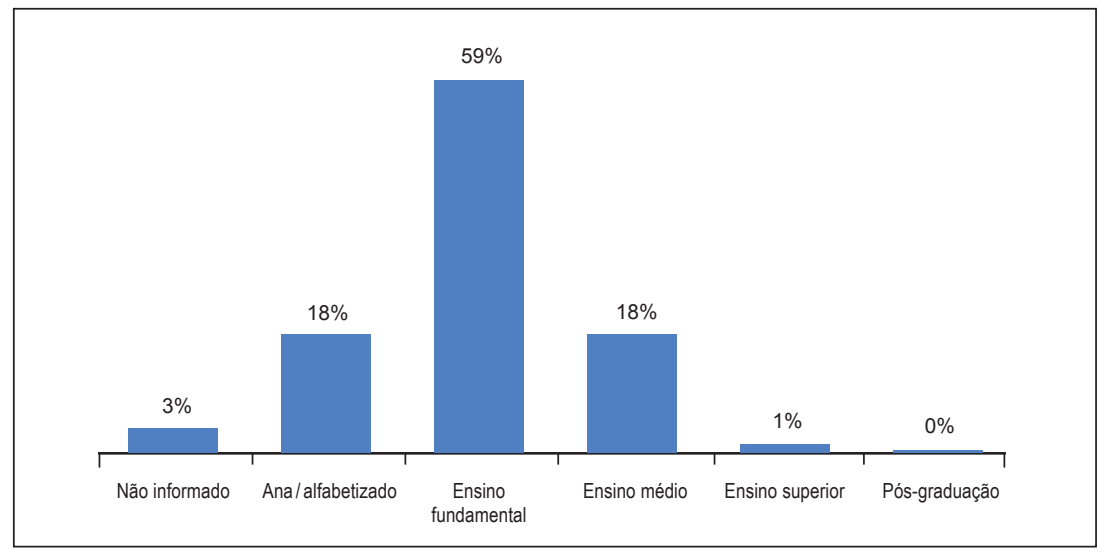

Fonte: BRASIL. Ministério da Justiça. Departamento Penitenciário Nacional - Sistema Integrado de Informação Penitenciária(Infopen). Brasília, 2011. Disponívelem: $<$ http://portal.mj.gov.br/data/Pages/MJD 574E9CEITEMIDC37B2AE94C6840068B1624D28407509CPTBRNN.htm>. Acesso em: 10 jun. 2011. Org.: Os autores.

Esse panorama fica mais claro com os dados relacionados ao grau de instrução. Do total de presos, $77 \%$ não haviam passado do ensino fundamental. Podemos afirmar que a maioria das pessoas encarceradas é de baixíssima escolaridade. Novamente convém ressaltar as contribuições de Wacquant (2001), que analisa a passagem do modelo taylorista/fordista para o neoliberal. Essa passagem implicou no condicionamento de um novo perfil de trabalhador mais técnico e qualificado e na desqualificação de antigos perfis de trabalhadores para a afirmação de um novo. A reclusão que antes visava o controle das populações desviantes passa a assumir um lugar central no sistema de controle do mercado de trabalho desqualificado, guetos urbanos com vistas a apoiar a disciplina do trabalho assalariado dessocializado. 
Juntamente com a crise do Welfare State, essas mudanças formaram uma massa de desprovidos que aumentaram o número de desempregados. Segundo o autor, o sistema penitenciário estaria servindo como um depósito da massa de desempregados cumprindo um papel de limpeza e higienização dos excluídos da sociedade. A luta contra o crime serviu como "[...] pretexto e trampolim para uma reformulação do perímetro e das funções do Estado [...]", no enxugamento do welfare state e inchaço dos setores policiais, correcionais (Wacquant, 2008, p. 10). Sua análise do sistema penitenciário francês e norteamericano demonstra os mesmos problemas; e o Brasil, com uma massa de pessoas de baixa escolaridade, não foge à regra.

Gráfico 10. Percentual de presos por cor de pele/etnia em 2010 no Brasil ${ }^{10}$

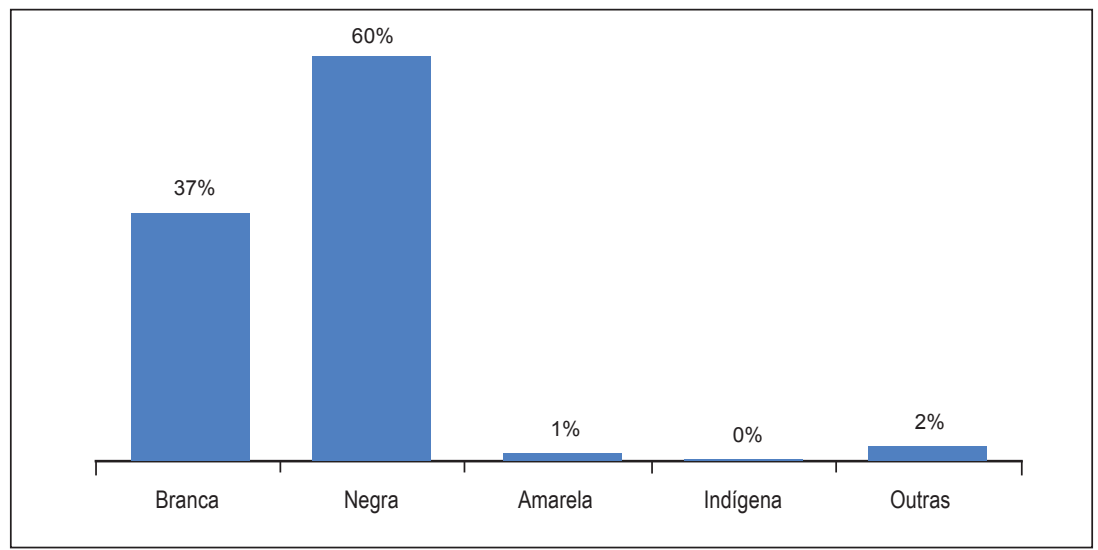

Fonte: BRASIL. Ministério da Justiça. Departamento Penitenciário Nacional - Sistema Integrado de InformaçãoPenitenciária (Infopen). Brasília, 2011. Disponívelem: $<$ http://portal.mj.gov.br/data/Pages/MJD 574E9CEITEMIDC37B2AE94C6840068B1624D28407509CPTBRNN.htm>. Acesso em: 10 jun. 2011; Org.: Os autores.

Os dados demonstram maior gravidade quando se leva em conta a cor das pessoas encarceradas e reforçam a discussão já desenvolvida na literatura. $60 \%$ são negros enquanto $37 \%$ são brancos. Indicadores de vulnerabilidade analisados comparativamente entre a população evidenciam a diferença marcante entre os negros e os brancos no Brasil.

O índice de desenvolvimento humano (IDH - 2000) entre os brancos era de 0,814 enquanto que o dos negros de 0,703 . O IDH dos negros no ano 2000 era inferior ao dos brancos em $1991(0,745)$. Outros indicadores, como a

\footnotetext{
${ }^{10}$ A categoria negra é o resultado do somatório entre o número de declarados "negros" e "pardos".
} 
intensidade da pobreza, também ressaltavam essa discrepância: enquanto para os brancos as taxas indicavam 47,43, entre os negros esta taxa apontava 49,29.

Para Coelho (2005a), os estereótipos de cor parecem funcionar efetivamente, especialmente no que tange o acesso diferencial à justiça por meio de marcadores sociais. Nesta perspectiva, Adorno (1989, p. 43) aponta que apesar da maioria dos sentenciados estarem inseridos no grupo de brancos, tanto para reincidentes como para não-reincidentes, $65 \%$ e $74 \%$ respectivamente, a diferença acentua-se quando se comparam reincidentes e não-reincidentes da cor negra.

Adorno (1996) descreve que os réus negros tendem a ser punidos mais severamente em comparação aos réus brancos, apesar de partilharem de características socioeconômicas semelhantes. A justiça penal ao ser mais severa para com os criminosos negros do que com brancos expressaria a desigualdade de direitos que compromete o funcionamento e a consolidação da democracia na sociedade brasileira.

De 2005 a 2007, o crescimento do número de presos reicidentes foi de 37.776 pessoas. Enquanto que no ano de 2005, o Infopen registrava o número de 36.663 pessoas que haviam voltado pela segunda vez ao sistema prisional, em 2007, 74.439 de 422.373 presos eram reicidentes. Significa que $18 \%$ de toda a população carcerária não foi "recuperada". Salla (2003), também aponta a carência de estudos consistentes sobre as taxas de reincidência criminal no Brasil. O material existente refere-se a levantamentos parciais da polícia que apontam para mais de $50 \%$ e revelam que a reinserção do indivíduo não é cumprida.

Em que medida tais apontamentos podem ser ilustrativos dos dados observados nos gráficos? É um questionamento a ser trabalhado. A justiça criminal privilegia a população que se torna refém de certos tipos específicos de criminalidade, muitas vezes, causados pelo baixo e restrito acesso a bens de consumo. Além disso, existem inúmeras barreiras simbólicas que separam grupos minoritários (neste caso não minoritários) do restante da sociedade. Estabelece-se um padrão específico de cidadão, como aquele que cumpre com suas obrigações deixando suas contas pagas e ficando com o nome "limpo na praça". O processo de criminalização se dá entre os jovens do sexo masculino, que cometeram pequenos delitos e pertencentes a parcelas marginalizadas da sociedade.

Segundo Macaulay (2006), o aumento da população prisional refere-se mais ao resultado de políticas que aprisionam suspeitos de modo rotineiro do que reflexo do incremento das taxas de criminalidade, o que embasa uma ideologia de que a "prisão funciona" por falta de alternativas. Wacquant (2001), no mesmo sentido, considera uma "aberração" o caso francês de incremento 
nas taxas penitenciárias, pois a própria criminologia não encontrou em nenhum lugar a existência de correlação entre a taxa de encarceramento e o nível de criminalidade. Este argumento também é reforçado por Lemgruber (2001, p. 14), que ressalta a inexistência de "[...] estudo conclusivo que demonstre inequivocamente o impacto benéfico da taxa de encarceramento na redução geral da criminalidade, e nem mesmo na diminuição dos crimes mais graves".

\section{Prender resolve?}

Com o objetivo de avaliar se o incremento constante das taxas da população prisional reduz a criminalidade, realizamos algumas análises inferenciais preliminares a fim de testar essa associação. O teste de regressão (apêndice B) é utilizado neste trabalho para verificar quais tipos de ocorrências criminais possuem maior impacto sobre a taxa da população prisional, ou seja, qual a combinação de variáveis independentes (ocorrências criminais) explica melhor a dependente (taxa da população prisional); e qual das preditoras possui maior capacidade explicativa. Como critério para a seleção de variáveis, realizamos testes de correlação ${ }^{11}$ entre a taxa da população prisional no período de $2006^{12}$ e as taxas de ocorrências criminais registradas pelas policias civis no ano de 2005. As taxas de ocorrências criminais são as seguintes (ver apêndice D): 1) taxa de crimes violentos letais, 2) taxa de crimes violentos não letais, 3) taxa de crimes violentos contra o patrimônio, 4) taxa de delitos de trânsito, 5) taxa de delitos envolvendo drogas, 6) taxa de homicídios dolosos, 7) taxa de tentativa de homicídios, 8) taxa de lesões corporais, 9) taxa de estupro, 10) taxa de atentado violento ao pudor, 11) taxa de extorsão mediante sequestro, 12) taxa de roubos e 13) taxa de furto.

Os testes são realizados por unidade da federação, já que os dados disponibilizados pelo Ministério da Justiça estão nesse nível de agregação, o ideal seria que esses dados estivem em um grau de desagregação maior, regiões intraestados, mesorregiões, microrregiões, etc. Com um número reduzido de casos, apenas 27, os resultados podem apresentar valores com inúmeras limitações, no entanto, com todos esses problemas, optamos trabalhar com as

\footnotetext{
${ }^{11}$ Como se trata de variáveis mensuradas quantitativamente, o teste de correlação escolhido é o do "coeficiente de correlação de Pearson". No entanto, nas palavras de Barbetta (1994, p. 246 - grifo do autor), "[...] o conceito de correlação refere-se a uma associação numérica entre duas variáveis, não implicando necessariamente, numa relação de causa-e-efeito, ou mesmo numa estrutura com interesses práticos". Ou seja, o teste de correlação serve como uma ferramenta complementar na análise do problema em observação e não como uma representação de causalidade. $\mathrm{O}$ teste completo encontra-se no apêndice $\mathrm{C}$.

12 As taxas referentes às ocorrências criminais e de encarceramento referem-se ao resultado do evento por 100.000 habitantes.
} 
informações no intuito de incentivar e pressionar os órgãos de segurança pública na elaboração de estatísticas mais confiáveis e na melhora da disponibilização.

O teste de correlação de Pearson $^{13}$ entre a taxa da população prisional e as ocorrências criminais apresenta alguns resultados iniciais interessantes. Podemos notar que a taxa da população prisional possui um relacionamento positivo com variáveis relacionadas ao ataque da propriedade e que os algozes são "facilmente" identificados pelas vítimas. A taxa de crimes violentos letais não apresenta correlação, isso vai ao encontro de muitos estudos que evidenciam a inoperância da polícia judiciária em investigar esses crimes, bem como, do próprio sistema de justiça em cumprir seu papel em relação ao julgamento e apreciação dos inquéritos e processos criminais. Em relação às tentativas de homicídios, a correlação é bastante alta $(0,706)$. $\mathrm{O}$ fato de o homicídio não ser consumado resulta na possibilidade da vítima em denunciar seu algoz, isso permite que as instituições policiais possuam mais recursos para a investigação.

Em resumo, o estudo inicial de correlações parece evidenciar a inoperância dos órgãos de justiça em agir nos crimes que necessitam de ampla investigação, como é o caso dos homicídios. Com graus de correlação tão altos (em algumas variáveis), os números poderiam evidenciar a eficácia do sistema prisional, isto é, à medida que as ocorrências criminais acontecem o sistema prisional absorve os algozes. De qualquer forma, essa eficácia é seletiva, pois não abrange a totalidade das ocorrências criminais, como é o caso da taxa de atentados violentos contra a pessoa.

Constatamos também que as ocorrências criminais caminham em um mesmo compasso com as taxas de encarceramento, contudo, não significam um decréscimo nas taxas de ocorrências criminais. Se tomarmos como exemplo o período de 2004 a 2005 no território nacional, a criminalidade em suas diversas modalidades passou de 4.200.298 para 4.990.742 ${ }^{14}$ e o crescimento da população prisional passou de 336.358 para 361.402 . A população prisional cresceu e as ocorrências criminais acompanharam esse mesmo processo. Além disso, o estudo de correlação não possui capacidade de explicação da variável dependente, isto é, não é possível evidenciar a causalidade da taxa da população prisional.

No intuito de verificar quais variáveis independentes apresentaram altos coeficientes de correlação e possuem maior capacidade explicativa para a taxa da população prisional, recorremos ao estudo de regressão stepwise. Este

${ }^{13}$ Os estados do Paraná, Amapá e Mato Grosso do Sul foram retirados do teste por se caracterizarem como outliers, isto é, ficarem em pontos dispersos no diagrama de dispersão.

${ }^{14}$ A taxa de 2004 foi de 1.598 .834 crimes por 100.000 habitantes; em 2005 esse número passa para 1.680 .843 crimes por 100.000 habitantes. 
teste permite selecionar variáveis que se adequam melhor à reta da equação, introduzindo e excluindo as variáveis mais significativas no modelo (Draper e Smith, 1966). ${ }^{15}$

De todas as variáveis utilizadas no modelo, apenas a taxa de tentativa de homicídios obteve significância relevante capaz de explicar a taxa da população prisional. O restante das ocorrências criminais foi retirado do modelo, porque seus coeficientes parciais de regressão não atingiram o nível mínimo de significância, 0,05 . Podemos perceber que os dados relativos à análise descritiva confirmam-se na análise inferencial, ou seja, de todas as ocorrências criminais, apenas uma, com grandes limitações é capaz de explicar o crescimento da taxa da população prisional. Com base nesses dados, parece-nos evidente afirmar que prender não é sinônimo de redução da criminalidade.

\section{Considerações finais}

O filósofo italiano Agamben tece contribuições interessantes para compreender a política contemporânea, especialmente a partir dos conceitos de estado de exceção, campo e homo sacer. A exceção "[...] é a estrutura originária na qual o direito se refere à vida e a inclui em si através da própria suspensão" e possui como característica ainda o fato de incluir o vivente por meio da sua própria suspensão (Agamben, 2010, p. 35). Quando o estado de exceção passa a ser desejado, a norma torna-se indiscernível da exceção.

Nesse contexto, o campo é compreendido como a estrutura em que o estado de exceção é realizado normalmente, ou seja, o campo é a própria expressão do estado de exceção. Além disso, "[...] o campo é um híbrido de direito e de fato, no qual os dois termos tornaram-se indiscerníveis" (Agamben, 2010, p. 166 - grifo do autor). Trata-se de uma indistinção entre lícito e ilícito, exceção e regra, é a impossibilidade de decisão entre fato e direito. O nascimento do campo é um evento que marca de forma decisiva o próprio espaço político da modernidade. Deste modo, Agamben (2010, p. 170) fornece-nos algumas pistas para caracterizar a emergência de um campo:

Se a essência do campo consiste na materialização do estado de exceção e na consequente criação de um espaço em que a vida nua e a norma entram em um limiar de indistinção, deveremos admitir, então, que nos encontramos virtualmente na presença de um campo toda vez que é criada uma tal estrutura, independentemente da natureza dos crimes que aí são cometidos e qualquer que seja a sua denominação ou topografia específica.

\footnotetext{
${ }^{15} \mathrm{O}$ teste de regressão stepwise serve como critério para a seleção de variáveis que não possuem uma trajetória teórica de análise.
} 
Consideramos que a aproximação, ainda que muito breve com Agamben, pode auxiliar a compreender a situação das prisões brasileiras enquanto um campo. ${ }^{16}$ Nas prisões brasileiras acumulam-se inúmeras exceções, violações de direitos humanos, condições indignas para os presidiários, o que demonstramos no artigo através dos seguintes fatores: incremento avassalador de $1.107 \%$ da taxa de óbitos criminais nos presídios de 1995 a 2010; ênfase na construção e ampliação de presídios e quantia irrisória destinada às atividades de capacitação dos presos; crescimento no número de presos provisórios; jovens e negros como alvos preferenciais do processo de criminalização e seletividade do sistema penal.

As delegacias e as prisões brasileiras acumulam presos provisórios e definitivos por períodos que ultrapassam o limite de qualquer provisoriedade e institucionalizam condições insalubres. Definitivamente, tais arbitrariedades podem nos fornecer elementos para compreender o sistema prisional brasileiro nos termos de um campo, no qual direito e fato tornam-se indiscerníveis.

Por mais que muitos dos dados apresentados e das próprias análises desenvolvidas ocupem um certo "lugar-comum" no debate sobre segurança pública, consideramos que o panorama desenhado do sistema prisional brasileiro contribui para a qualificação, acompanhamento e crítica das políticas de segurança pública. Além disto, é de grande valia que as discussões da agenda pública não sejam alimentadas apenas por crises que nos lembram constantemente que a exceção tornou-se a regra.

\section{Referências}

ADORNO, S. BORDINI, E. Reincidência e reincidentes penitenciários em São Paulo, 1974-1985. Revista Brasileira de Ciências Sociais, São Paulo, v. 9, n. 3, p. 70-94, fev. 1989.

ADORNO, S. Racismo, criminalidade e justiça penal: réus brancos e negros em perspectiva comparativa. Estudos Históricos, Rio de Janeiro, n. 18, p. 1-22, 1996.

. Crimen, punición y prisiones en Brasil: un retrato sin retoques. Quórum, Alcalá de Henares, n. 16, p. 41-49, Invierno 2006.

AGAMBEN, G. Estado de exceção. São Paulo: Boitempo, 2004.

${ }^{16}$ Neste livro, Agamben observa que as prisões são partes constitutivas do direito carcerário, o que não está fora do ordenamento normal, mas sim é um âmbito particular do direito penal. Contudo, as prisões brasileiras acumulam arbitrariedades. Duarte também realiza esta aproximação: “[...] tais prisões são um espaço ambíguo de inclusão (no sistema jurídico formal) e de total exclusão do prisioneiro da legislação e da cidadania, o que permite que este, antes de ser considerado um cidadão portador de direitos temporariamente limitados, seja considerado como a encarnação excessiva - há sempre um excedente de prisioneiros nestas prisões - da vida que não merece viver, que pode ser descartada e assassinada sem que se cometa delito, o que explica o altíssimo índice de mortes violentas que ocorrem nestas instituições peculiares, que não se ocupam da reintegração do preso, mas de sua exclusão e eliminação do convívio social” (Duarte, 2008, p. 15-16). 
AGAMBEN, G. Homo sacer: o poder soberano e a vida nua. 2. ed. Belo Horizonte: Editora da UFMG, 2010.

BARBETTA, P. A. Estatística aplicada às Ciências Sociais. Florianópolis: Editora da UFSC, 1994.

BRASIL. Ministério da Justiça. Departamento Penitenciário Nacional - Sistema Integrado de Informação Penitenciária (Infopen). Brasília, 2011. Disponível em: $<$ http://portal.mj.gov.br/data/Pages/MJD574E9CEITEMIDC37B2AE94C6840068 B1624D28407509CPTBRNN.htm>. Acesso em: 10 jun. 2011.

BRASIL. Ministério da Justiça. Informações Infopen. Brasília, 2011b. Disponível em: $<$ http://portal.mj.gov.br/data/Pages/MJD574E9CEITEMID598A21D892E444B5943 A0AEE5DB94226PTBRIE.htm>. Acesso em: 10 jun. 2011.

BRASIL. Ministério da Justiça. Histórico do Programa Nacional de Penas e Medidas Alternativas. Brasília, 2008. Disponível em: $<$ http://portal.mj.gov.br/services/Document Management/FileDownload.EZTSvc.asp?DocumentID=\%7B4F489369-7498-4379A409-A97F7374FB10\%7D\&ServiceInstUID=\%7B4AB01622-7C49-420B-9F7615A4137F1CCD\%7D>. Acesso em: 24 nov. 2011.

BRASIL. Ministério da Justiça. Fundo Penitenciário Nacional: Funpen em números. Brasília, 2010. Disponível em <http://portal.mj.gov.br>. Acesso em: 12 maio 2011.

COELHO, E. C. A administração da Justiça Criminal no Rio de Janeiro: 1942-1967. A Oficina do Diabo e outros estudos sobre criminalidade. Rio de Janeiro: Record, 2005a.

A criminalização da marginalidade e marginalização da criminalidade. $A$ $\overline{\text { Oficina }}$ do Diabo e outros estudos sobre criminalidade. Rio de Janeiro: Record, 2005b.

Oficina do diabo. A Oficina do Diabo e outros estudos sobre criminalidade. Rio de Janeiro: Record, 2005c.

. Sobre sociólogos, pobreza e crime. A Oficina do Diabo e outros estudos sobre criminalidade. Rio de Janeiro: Record, 2005d.

DRAPER, N.; SMITH, H. Applied regression analysis. New York: John Willey, 1966.

DUARTE, A. De Michel Foucault a Giorgio Agamben: a trajetória do conceito de biopolítica. Fenomenologia Hoje III - Bioética, biotecnologia, biopolítica. Porto Alegre: Edipucrs, 2008. p. 63-88.

LEMGRUBER, J. Verdades e mentiras sobre o sistema de justiça criminal. Revista CEJ, Brasília, n. 15, p. 12-29, set.-dez. 2001.

LEVIN, J.; FOX, J. A. Estatística para as Ciências Humanas. 9. ed. São Paulo: Prentice Hall, 2004.

MACAULAY, F. Prisões e política carcerária. In: LIMA, Renato; PAULA, Liana (Orgs.). Segurança pública e violência: o estado está cumprindo o seu papel? São Paulo: Contexto, 2006.

MISSE, M. Cinco teses equivocadas sobre a criminalidade urbana no Brasil: uma abordagem crítica, acompanhada de sugestões para uma agenda de pesquisas no Brasil, Rio de Janeiro, 1995. Disponível em: <http://www.necvu.ifcs.ufrj.br>. Acesso em: 10 maio 2011. 
PERES, M. F. T.; CARDIA, N.; SANTOS, P. C. Homicídios de crianças e jovens no Brasil: 1980-2002. Núcleo de Estudos da Violência. Universidade de São Paulo: NEV/USP, 2006.

SALLA, F. Os impasses da democracia brasileira: o balanço de uma década de políticas para as prisões no Brasil. Lusotopie, Bordeaux, 2003.

SALLA, F.; BALLESTEROS, Paula R. Democracia, direitos humanos e condições das prisões na América do Sul. Research project of Geneva Academy of International Humanitarian Law and Human Rights, 2008.

SAPORI, L. F. Segurança pública no Brasil: desafios e perspectivas. São Paulo: Fundação Getúlio Vargas, 2009.

WACQUANT, L. A aberração carcerária à moda francesa. Dados - Revista de Ciências Sociais, Rio de Janeiro, v. 47, n. 2, p. 215-232, 2004. . As prisões da miséria. Rio de Janeiro: Jorge Zahar, 2001.

. O lugar da prisão na nova administração da pobreza. Novos Estudos Cebrap, São Paulo, n. 80, p. 9-19, 2008.

WAISELFISZ, J. J. Mapa da violência 2010: anatomia dos homicídios no Brasil. São Paulo: Instituto Sangari, 2010.

Data de recebimento: 07/12/2011.

Data de aprovação: 30/03/2013.

Autor correspondente:

Felipe Mattos Monteiro

Rua Santana, 1690 - Centro

85301-200 Laranjeiras do Sul, PR 


\section{APÊNDICE A \\ Lista dos grupos de crimes analisados no gráfico}

"Crimes contra a pessoa": Homicídio Simples (Art. 121, caput), Homicídio Qualificado (Art. 121, § 2o), Sequestro e Cárcere Privado (Art. 148) / "Crimes contra o patrimônio": Furto Simples (Art. 155), Furto Qualificado (Art. 155, $\S 4^{\mathrm{O}}$ e $\S 5^{\circ}$ ), Roubo Qualificado (Art. 157, $\S 2^{\circ}$ ), Latrocínio (Art. 157, $\S 3^{\circ}$ ), Extorsão (Art. 158), Extorsão Mediante Seqüestro (Art. 159), Apropriação Indébita (Art. 168), Apropriação Indébita Previdenciária (Art. 168-A), Estelionato (Art. 171), Receptação (Art. 180), Receptação Qualificada (Art. 180, Parágrafo $1^{\circ}$ ), Roubo Simples (Art. 157) / "Crimes contra os costumes": Estupro (Art. 213), Atentado Violento ao Pudor (Art. 214), Corrupção de Menores (Art. 218), Tráfico Internacional de Pessoas (Art. 231), Tráfico Interno de Pessoas (Art. 231A) / "Crimes contra a paz pública": Quadrilha ou Bando (Art. 288) / "Crimes Contra a Fé Pública": Moeda Falsa (Art. 289), Falsificação de Papéis, Selos, Sinal e Documentos Públicos, Falsidade Ideológica (Art. 299), Uso de Documento Falso (Art. 304) / "Crimes Contra a Administração Pública" e "Crimes Praticados Por Particular Contra a Administração Pública": Peculato (Arts. 312 e 313), Concussão e Excesso de Exação (Art. 316), Corrupção Passiva (Art. 317), Corrupção Ativa (Art. 333), Contrabando ou Descaminho (Art. 334) / "Legislação Específica": Estatuto da Criança e do Adolescente (Lei no 8.069, de 13/01/1990), Genocídio (Lei no 2.889, de 01/10/1956), Crimes de Tortura (Lei no 9.455, de 07/04/1997), Crimes Contra o Meio Ambiente (Lei no 9.605, de 12/02/1998), Lei Maria da Penha - Violência Contra a Mulher (Lei no 11.340, de 7/8/2006)."Entorpecentes": Tráfico de Entorpecentes, Tráfico Internacional de Entorpecentes / "Estatuto do Desarmamento": Porte Ilegal de Arma de Fogo de Uso Permitido (Art. 14), Disparo de Arma Fogo (Art. 15), Posse ou Porte Ilegal de Arma de Fogo de Uso Restrito (Art. 16), Comércio Ilegal de Arma de Fogo (Art. 17), Tráfico Internacional de Arma de Fogo (Art. 18). 


\section{APÊNDICE B}

\section{Regressão Stepwise - taxa da população prisional e ocorrências criminais ${ }^{17}$}

\section{Coefficients $^{\text {a }}$}

\begin{tabular}{|l|c|c|c|c|c|}
\hline \multirow{2}{*}{ Model } & \multicolumn{2}{|c|}{$\begin{array}{c}\text { Unstandardized } \\
\text { coefficients }\end{array}$} & $\begin{array}{c}\text { Standardized } \\
\text { coeffcients }\end{array}$ & \multirow{2}{*}{ t } & \multirow{2}{*}{ Sig. } \\
\cline { 2 - 5 } & B & Std. Error & Beta & & \\
\hline 1 (Constant) & 82,797 & 25,591 & 0,706 & 3,235 & 0,004 \\
Tentativa de homicídios & 4,568 & 1,001 & & 4,564 & 0,000 \\
\hline
\end{tabular}

a Dependent Variable: Taxa de encarceramento 2006.

\section{Excluded variables ${ }^{b}$}

\begin{tabular}{|c|c|c|c|c|c|}
\hline \multirow{2}{*}{ Model } & \multirow{2}{*}{ Beta } & \multirow{2}{*}{$\mathbf{t}$} & \multirow{2}{*}{ Sig. } & \multirow{2}{*}{$\begin{array}{c}\text { Partial } \\
\text { Correlation }\end{array}$} & $\begin{array}{l}\text { Collinearity } \\
\text { Statistcs }\end{array}$ \\
\hline & & & & & Tolerance \\
\hline 1 Crimes violentos não letais & $0,333^{a}$ & 0,868 & 0,395 & 0,191 & 0,164 \\
\hline Delitos de trânsito & $0,194^{b}$ & 1,064 & 0,300 & 0,231 & 0,714 \\
\hline Delitos envolvendo drogas & $0,277^{a}$ & 1,509 & 0,147 & 0,320 & 0,669 \\
\hline Lesões corporais & $0,154^{a}$ & 0,751 & 0,461 & 0,166 & 0,584 \\
\hline Estupro & $0,157^{a}$ & 0,830 & 0,416 & 0,182 & 0,680 \\
\hline Atentado violento ao pudor & $0,133^{b}$ & 0,754 & 0,460 & 0,166 & 0,780 \\
\hline Furto & $0,282^{a}$ & 1,493 & 0,151 & 0,317 & 0,634 \\
\hline
\end{tabular}

a Predictores in the model: (Constant), tentativa de homicídios.

${ }^{\mathrm{b}}$ Dependent variable: Taxa de encarceramento 2006.

${ }^{17}$ Method: Stepwise (Criteria: Probability-of-F-to-enter $<=$, 0,50, Probability-of-F-toremove $>=0,100$ ) $/$ Adjusted $R$ Square $=0,474 /$ Sig. $F$ Change $=0,000$. 


\begin{tabular}{|c|c|c|c|c|c|c|c|c|c|c|c|c|c|}
\hline & 总 & ฮิ & 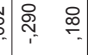 & 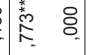 & $\left(\begin{array}{c}* \\
0 \\
\infty\end{array}\right.$ & 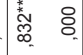 & مِ & $\begin{array}{ll}0 \\
0 \\
0\end{array}$ & 悉 8 & 密 & 势 & 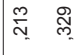 & - \\
\hline & 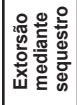 & 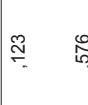 & 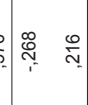 & 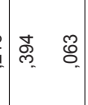 & {$\left[\begin{array}{cc}0 \\
\hdashline\end{array}\right.$} & $\begin{array}{ll}8 & 8 \\
0 & \&\end{array}$ & 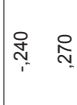 & 命 & 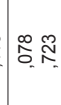 & 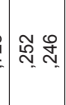 & 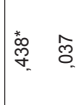 & - & 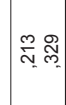 \\
\hline & 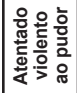 & 芯 & 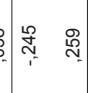 & $\begin{array}{ll}0 \\
0\end{array}$ & 竎 & 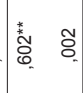 & 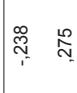 & 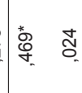 & $\frac{*}{5}$ & $\left(\begin{array}{ll}* \\
\hdashline\end{array}\right)$ & - & 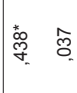 & 总 \\
\hline 氜 & $\begin{array}{l}\text { 을 } \\
\text { 产 } \\
\text { 山ै }\end{array}$ & 赵 & 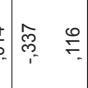 & 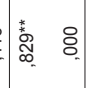 & 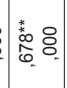 & {$\left[\begin{array}{ll}* & 0 \\
i 0 & 0 \\
i n & 0\end{array}\right.$} & 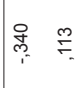 & 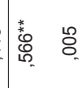 & 表 & - & 㐘 8 & 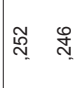 & 军 \\
\hline 汤 & 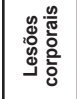 & 蒡 & 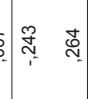 & {$\left[\begin{array}{ll}* \\
\stackrel{*}{*} & 8 \\
\hdashline & 0\end{array}\right.$} & 㐘 & 密 & 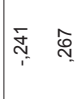 & 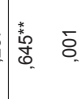 & - & 卷 & $\stackrel{*}{*}$ & 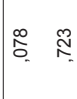 & $\begin{array}{ll}0 \\
0 \\
0\end{array}$ \\
\hline 范 & 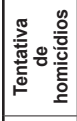 & : & 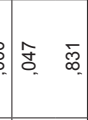 & $\begin{array}{ll}* \\
\sigma & 8 \\
\sigma & 8\end{array}$ & 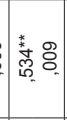 & $\mid \begin{array}{ll}0 & 0 \\
0 & 0 \\
0 & 0 \\
0 & 0\end{array}$ & $\because$ & - & 娄 & 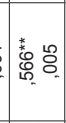 & 蓠 & 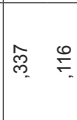 & : \\
\hline $\begin{array}{l}0 \\
0 \\
0 \\
0 \\
0\end{array}$ & 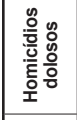 & $\stackrel{\mathbb{N}}{\underset{c}{*} .}$ & 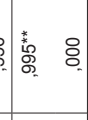 & {$\left[\begin{array}{ll}8 & 0 \\
\hdashline & 0\end{array}\right.$} & {$\left[\begin{array}{ll}\infty & \infty \\
\hdashline & \infty \\
r & 0\end{array}\right]$} & $\begin{array}{cc}\tilde{y} & \hat{\infty} \\
0 & 0\end{array}$ & - & $\notin$ & 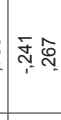 & 晜 & 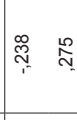 & 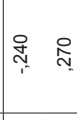 & 象 \\
\hline 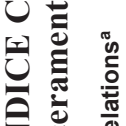 & 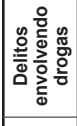 & 走 & 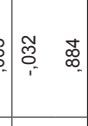 & 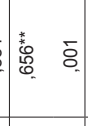 & 类员 & - & 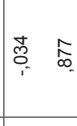 & 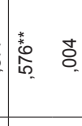 & 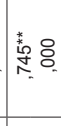 & 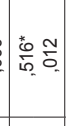 & : & $\stackrel{8}{\circ}$ & 告。 \\
\hline ¿. & 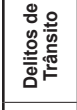 & 苾 & 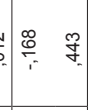 & $\begin{array}{ll}\frac{*}{2} & 8 \\
\frac{0}{2} & 8\end{array}$ & - & 类 & \begin{tabular}{ll}
$\stackrel{\infty}{\infty}$ & $\infty$ \\
\hdashline. & $\stackrel{\infty}{r}$
\end{tabular} & 箬 & 㐘 & 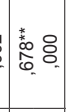 & 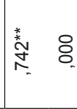 & స్లి & . \\
\hline שี & 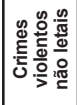 & . & 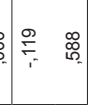 & - & 卷总 : & $\begin{array}{ll}* & \bar{s} \\
0 & \overline{8} \\
0 & 0\end{array}$ & $\stackrel{8}{\circ}$ & 类 & 喜。 & : & 恙 8 & 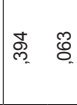 & 悉 \\
\hline$\stackrel{0}{\stackrel{0}{0}}$ & 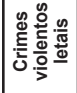 & 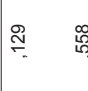 & - & 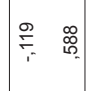 & 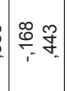 & 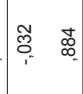 & 表 & $\bar{\delta}$ & 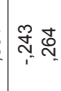 & $\hat{m}=0$ & 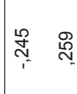 & 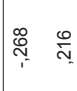 & 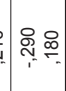 \\
\hline 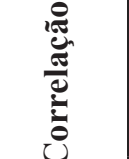 & 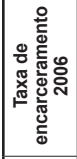 & - & 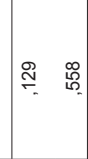 & \begin{tabular}{ll}
$*$ \\
2 & 8 \\
\hdashline & 0
\end{tabular} & $\stackrel{*}{*}$ & 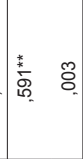 & 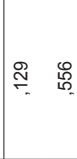 & $\begin{array}{ll}* \\
0 \\
0 & 8 \\
0 & 8\end{array}$ & 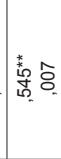 & 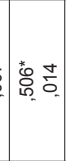 & 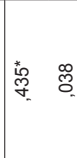 & $\begin{array}{ll}\cong & \infty \\
& 0\end{array}$ & 类 \\
\hline & & 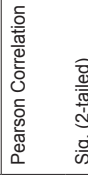 & 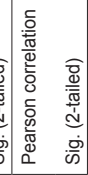 & 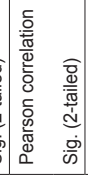 & 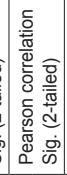 & 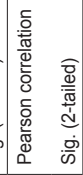 & 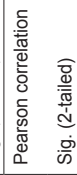 & 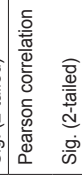 & 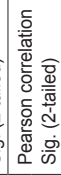 & 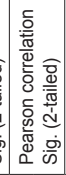 & 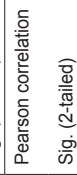 & 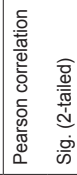 & 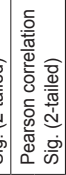 \\
\hline & & 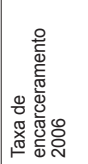 & 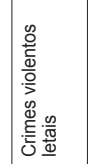 & 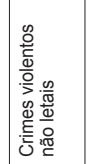 & 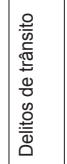 & 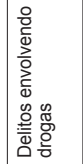 & 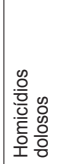 & 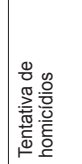 & 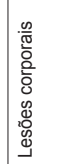 & \begin{tabular}{|l} 
을 \\
产 \\
w \\
w
\end{tabular} & 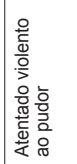 & 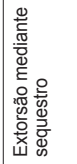 & 온 \\
\hline
\end{tabular}




\section{APÊNDICE D \\ Tipos de ocorrências criminais analisadas}

A taxa de crimes violentos intencionais é composta pela soma do número de ocorrências dos seguintes delitos: homicídio doloso; lesão corporal seguida de morte e roubo seguido de morte (latrocínio). Fonte: Ministério da Justiça MJ/Secretaria Nacional de Segurança Pública - Senasp/Secretarias Estaduais de Segurança Pública/Departamento de Pesquisa, Análise da Informação e Desenvolvimento de Pessoal em Segurança Pública - Coordenação Geral de Pesquisa/Instituto Brasileiro de Geografia e Estatística - IBGE.

Taxa de crimes violentos não letais é composta pela soma do número de ocorrências dos seguintes delitos: atentado violento ao pudor, estupro, tentativa de homicídio e tortura. Fonte: Ministério da Justiça - MJ/Secretaria Nacional de Segurança Pública - Senasp/Secretarias Estaduais de Segurança Pública/ Departamento de Pesquisa, Análise da Informação e Desenvolvimento de Pessoal em Segurança Pública - Coordenação Geral de Pesquisa/Instituto Brasileiro de Geografia e Estatística - IBGE.

Taxa de crimes violentos contra o patrimônio é composta pela soma do número de ocorrências dos seguintes delitos: extorsão mediante sequestro; roubo de veículo, roubo de carga, roubo a ou de veículo de transporte de valores (carro-forte), roubo a instituição financeira, roubo a transeunte, roubo em transporte coletivo, roubo em estabelecimento comercial ou de serviços, roubo em residência, roubo com restrição de liberdade da vítima e outros roubos. Fonte: Ministério da Justiça - MJ/Secretaria Nacional de Segurança Pública - Senasp/ Secretarias Estaduais de Segurança Pública/Departamento de Pesquisa, Análise da Informação e Desenvolvimento de Pessoal em Segurança Pública - Coordenação Geral de Pesquisa/Instituto Brasileiro de Geografia e Estatística - IBGE.

Taxa de delitos de trânsito é composta pela soma do número de ocorrências dos seguintes delitos: homicídio culposo (acidente de trânsito); lesão corporal culposa (acidente de trânsito). Fonte: Ministério da Justiça - MJ/Secretaria Nacional de Segurança Pública - Senasp/Secretarias Estaduais de Segurança Pública/Departamento de Pesquisa, Análise da Informação e Desenvolvimento de Pessoal em Segurança Pública - Coordenação Geral de Pesquisa/Instituto Brasileiro de Geografia e Estatística - IBGE.

Taxa de delitos envolvendo drogas pela soma do número de ocorrências dos seguintes delitos: tráfico de drogas; uso e porte de drogas. Fonte: Ministério da Justiça - MJ/Secretaria Nacional de Segurança Pública - Senasp/Secretarias Estaduais de Segurança Pública/Departamento de Pesquisa, Análise da Informação e Desenvolvimento de Pessoal em Segurança Pública - Coordenação Geral de Pesquisa/Instituto Brasileiro de Geografia e Estatística - IBGE.

A taxa de lesões corporais é composta pelos seguintes delitos: lesão corporal seguida de morte, lesão corporal dolosa, outras lesões corporais culposas e outros crimes resultantes em lesão corporal. 